\title{
PERSEPSI MAHASISWA TERHADAP PELAYANAN PEMBELAJARAN ONLINE DI MASA PANDEMI COVID-19
}

\author{
Dwi Jatmoko1, Mahfudz Faizun² \\ 1,2 Universitas Muhammadiyah Purworejo \\ e-mail: ${ }^{1}$ dwijatmoko@umpwr.ac.id, ${ }^{2}$ mahfudzfaizun777@gmail.com
}

\begin{abstract}
ABSTRAK
Tujuan penelitian yang dilakukan ini untuk mengetahui, menganalisis, dan mencermati persepsi mahasiswa program studi pendidikan teknik otomotif terhadap pelayanan pembelajaran online pada masa pandemi corona atau covid-19 di Universitas Muhammadiyah Purworejo. Desain penelitian yang dilakukan dengan penelitian deskriptif kuantitatif dengan model pengambilan data jenis quesioner online (google form) terhadap mahasiswa Pendidikan Teknik Otomotif Fakultas Keguruan IImu Pendidikan Universitas Muhammadiyah Purworejo angkatan 2018 yang dipilih secara acak; dan teknik analisis data yang digunakan adalah analisis deskriptif. Hasil penelitian menunjukkan bahwa $82 \%$ mahasiswa mengetahui dan mampu menggunakan pembelajaran online, $72 \%$ mahasiswa mendukung pelaksanaan pembelajaran online, dan $67 \%$ mahasiswa menyatakan puas dengan pembelajaran online. Hasil data secara general, menghasilkan analisia bahwa persepsi mahasiswa Pendidikan Teknik Otomotif terhadap pembelajaran online dimasa covid 19 menyatakan berguna, dan dapat meningkatkan motivasi, memudahkan dan mengambil materi pembelajaran, serta dapat membantu kesiapan dalam pembelajaran online. Berdasarkan analisis yang peneliti lakukan mengambil maksud bahwa dalam penjelasan mahasiswa memiliki komitmen tinggi dalam hal pembelajaran jarak jauh atau online dimasa pandemi Covid-19 yaitu sebesar 88\%. Penilaian terhadap persepsi mahasiswa terhadap pelayanan pembelajaran online dengan memberikan peran yang besar dalam pelaksanaan pembelajaran online, yang dapat dilakukan dengan layanan google classroom dan zoom meeting sebagai platform pembelajaran.
\end{abstract}

Kata kunci: Persepsi Mahasiswa, Pembelajaran Online, Motivasi, Kepuasan

\section{PENDAHULUAN}

Corona Viruse Disease-19 yang terjadi di Negara Indonesia mengakibatkan perubahan kebijakan secara foundamental dalam dunia pendidikan mulai dari Sekolah Dasar sampai Perguruan Tinggi. Nadiem Anwar Makarim sebagai Menteri Pendidikan dan Kebudayaan RI telah mengeluarkan kebijakan untuk mengatur kegiatan pembelajaran selama wabah corona terjangkit di Indonesia. Hal tersebut dikeluarkan melalui Surat edaran Nomor 4 Tahun 2020, yaitu tentang Pelaksanaan Kebijakan Pendidikan dalam Masa Darurat Penyebaran Corona Virus Disease (Covid-19), 
tertanggal 24 Maret 2020. Ada enam kebijakan yang dijelaskan secara mendetail, yang paling mendasar yaitu merubah cara belajar mengajar mahasiswa dan dosen yaitu kebijakan belajar dari rumah (Work From Home). Kebijakan belajar dari rumah sangat merubah kebiasaan, ataupun budaya perilaku dosen dan mahasiswa selama masa pandemi. Selama ini dosen mengajar di kelas dengan mengajar di kampus yang memiliki fungsi belajar mengajar, dengan didukung oleh sarana penunjang proses belajar mengajar.

Kebijakan baru ini dosen dibuat berpikir dua kali karena masih mencari pola yang tepat bagaimana pembelajaran dari rumah bisa dilakukan. Program terbaik dengan melakukan pembelajaran berbasis dalam jaringan atau pembelajaran daring (online learning). Pembelajaran yang dilakukan pada masa pandemi ini sangat berbeda dengan pembelajaran konvensional. Dosen dan mahasiswa tidak bertatap muka langsung, melainkan dengan cara jarak jauh, yang memungkinkan dosen dan mahasiswa berada pada tempat yang berbeda. Secara positif pembelajaran daring sangat membantu keberlangsungan pembelajaran di masa pandemi ini. Dosen dan mahasiswa akan tetap aman berada pada tempat atau rumahnya masing-masing tanpa harus keluar rumah dan bertatap muka secara langsung. Namun, merubah pola atau kebiasaan sangatlah sulit, dan merupakan hal wajar ketika terjadi perubahan yang sangat cepat dan tidak terduga.

Kebiasaan yang berubah secara signifikan ini misalnya, dosen dan mahasiswa sangat mengandalkan perangkat komputer dan jaringan internet, itu yang pertama. Kedua, dosen dan mahasiswa harus mampu merubah gaya, strategi atau metode mengajar dan belajar. Ketiga, dosen dan mahasiswa harus mampu merubah gaya komunikasi selama pembelajaran daring. Banyak dosen yang tidak memperhatikan bagiaan yang ketiga ini, yaitu kurangnya pemahaman dan penerapan dosen dalam berkomunikasi dengan mahasiswanya. Dosen biasanya berkomunikasi satu atau dua arah di kampus, dengan bertatap muka secara secara langsung melakukan diskusi dan latihan secara bersama - sama. Dosen akan lebih mudah memberikan pemaparan dan penjelasan suatu materi, sedangkan mahasiswa akan lebih mudah dalam memahami dan berdiskusi langsung kepada dosennya. Dengan kejadian pandemi ini, hal ini 
menjadi sangat sulit untuk tetap mempertahankan kebiasaan gaya komunikasi dosen tersebut. Maka dari itu, perlu adanya perubahan gaya komunikasi dosen selama atau saat pandemi Covid-19 ini. Komunikasi yang dipakai tentunya, yang bersifat jarak jauh dalam hal ini dikenal sebagai komunikasi daring. Komunikasi ini, memungkinkan dosen sebagai komunikator dan mahasiswa sebagai komunikan melakukan komunikasi melalui jaringan internet atau dunia maya. Tujuannya yaitu, bisa dikendalikan secara jarak jauh, efisiensi waktu jadi bisa dilakukan kapan saja dan dimana saja. Menurut Novak (dalam Balaji, Al-Mahri, \& Malathi, 2016) dengan menggunakan online dapat meningkatkan interaktivitas dan efisiensi belajar karena memberikan mahasiswa potensi yang lebih tinggi untuk berkomunikasi lebih banyak dengan dosen, rekan, dan mengakses lebih banyak materi pembelajaran.

\section{METODE PENELITIAN}

Adapun metode yang penulis gunakan dalam penelitian adalah metode deskriptif kuantitatif. Menurut Sugiyono (2017: 5) pengertian dari metode penelitian adalah sebagai berikut metode penelitian dapat diartikan sebagai cara ilmiah untuk mendapatkan data yang valid dengan tujuan dapat ditemukan, dikembangkan, dan dibuktikan, suatu pengetahuan tertentu sehingga pada gilirannya dapat digunakan untuk memahami, memecahkan, dan mengantisispasi masalah. Penelitian deskriptif ini, dilakukan dengan survei terhadap mahasiswa pendidikan teknik otomotif Fakultas Keguruan dan Ilmu Pendidikan Universitas Muhammadiyah Purworejo.

Teknik pengumpulan data dengan menggunakan quisioner, dengan sampel mahasiswa angkatan 2018 yang dipilih secara acak. Tahapan yang dilakukan dalam penelitian ini adalah penyusunan instrumen quisioner yang akan digunakan untuk pengumpulan data. Informasi yang termuat dalam quesioner adalah pengetahuan tentang pembelajaran online, motivasi, dan kepuasan penggunaan internet. Quesioner yang telah disusun diuji validitas oleh pakar yang memahami pembelajaran online. Selanjutnya mengumpulkan data dengan quesioner yang telah divalidasi dari mahasiswa pendidikan teknik otomotif angkatan 2018 yang dipilih secara acak seban- 
yak 50 mahasiswa. Data yang diperoleh dari mahasiswa berupa data kualitatif dan kuantitatif, yang kemudian dilakukan analisis secara deskriptif.

\section{HASIL PENELITIAN DAN PEMBAHASAN}

Data yang diperoleh melalui quisioner berupa respon persepsi mahasiswa terhadap pembelajaran online selama pandemi Covid-19, dipersentasekan berdasarkan segi yang dianalisis secara deskriptif berdasarkan data responden yang diteliti. Pada aspek pelaksanaan kuliah dengan pembelajaran diperoleh data dari mahasiswa sebanyak 54\% menyatakan setuju dengan pembelajaran online, dan $46 \%$ mahasiswa menyatakan tidak setuju terhadap pelaksanaan perkuliahan dengan menggunakan pembelajaran online seperti terlihat pada gambar 1.

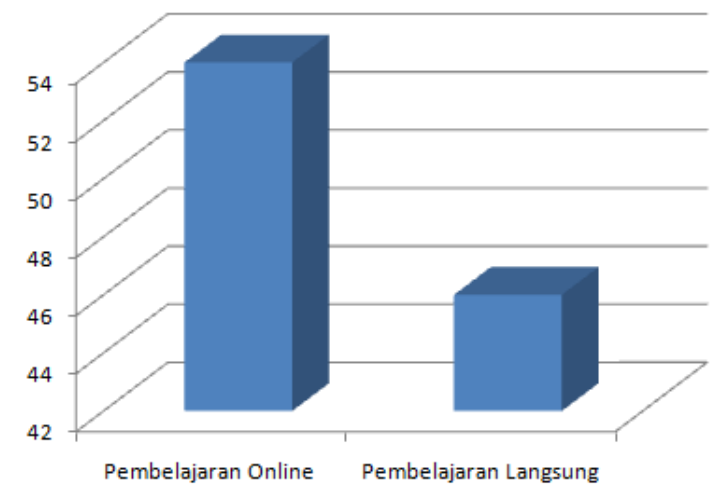

Gambar. 1 Tanggapan Mahasiswa tentang Perkuliahan Online

Pembelajaran Online (pembelajaran langsung) dapat diartikan sebagai upaya menghubungkan siswa atau peserta didik dengan sumber belajar yang secara fisik terpisah bahkan jarak jauh tetapi dapat saling berkomunikasi, berinteraksi secara langsung dan tidak langsung. Online yaitu bentuk pembelajaran atau kepelatihan jarak jauh yang memanfaatkan teknologi dan informasi, misalnya internet, video, teleconference, secara langsung dan tidak langsung. Semua media elektronik tersebut bertujuan membantu peserta didik agar bisa lebih memahami materi pelajaran. Sehingga Online yaitu pembelajaran dengan menggunakan bantuan perangkat elektronika secara langsung. Kegiatan Online termasuk dalam model pembelajaran individu. Pembelajaran Online sangat potensial karena siswa dan guru dapat mengakses materi secara luas dari berbagai sumber. Salah satu penjelasan dari 
pembelajaran Online, yaitu pengiriman materi atau pembelajaran langsung melalui suatu media elektronik seperti Internet, satellite broadcast, audio atau video tape, interactive televisi, dan computer based training.

Pembelajaran Online menggunakan teknologi elektronik untuk mengirim, mendukung, dan meningkatkan pengajaran, pembelajaran dan penilaian. Pembelajaran online merupakan bagian dari pembelajaran jarak jauh. Disamping itu, definisi pembelajaran online meliputi berbagai aplikasi dan proses seperti computer based learning, web-based learning, virtual classroom, dan lainnya. Sementara itu pembelajaran online merupakan bagian dari pembelajaran berbasis teknologi yang memberikan manfaat bagi mahasiswa dan dosen di masa pandemi Covid-19. Bagi mahasiswa, pembelajaran online merupakan alternatif belajar dibandingkan pembelajaran konvensional dosen, dimana pembelajaran dapat berlangsung di luar ruang kuliah, membentuk belajar mandiri, membantu menjadikan belajar sebagai belajar sepanjang masa dan mendorong untuk berinteraksi antara mahasiswa satu dengan yang lain. Sedangkan bagi dosen, pembelajaran online mengubah gaya belajar yang berdampak pada profesionalitas kinerja, memberi peluang menilai siswa dan mengevaluasi pembelajaran setiap siswa dan mengeksplorasi diri secara efisien (Singh, O'donoghue, \& Worton, 2005).

Pembelajaran melalui online memerlukan desain yang jelas, diantaranya terkait dengan komponen online. Menurut Kelly \& Nanjiani dalam wicaksono sebuah pembelajaran online harus memiliki tiga komponen dasar yang terdiri dari pengkomunikasian materi, kepelatihan, dan penilaian untuk hasil pembelajaran. Hasil analisis komponen pembelajaran online yang memperlihatkan lebih dari $86 \%$ mahasiswa menyatakan perlu adanya beberapa hal: 1) instruksional pembelajaran online, 2) planning atau rencana pembelajaran di kelas, 3) sumber belajar dan bahan ajar. Hasil analisis menunjukkan 54\% mahasiswa setuju dengan adanya pembelajaran dalam tahapan proses belajar yang akan dilakukan melalui pembelajaran online, sehingga mahasiswa dapat belajar mandiri secara terstruktur terlebih saat mahasiswa baru pertama kali menggunakan pembelajaran online di masa pandemi Covid-19. 
Selain itu, secara kontinyu dan jarak jauh dapat membantu proses tercapainya tujuan pembelajaran yang direncanakan oleh dosen. Hasil yang sama terlihat pada analisis rencana pembelajaran di kelas, hal ini memberikan manfaat untuk memberikan gambaran aktivitas pembelajaran yang akan dilakukan di dalam kelas online. Sehingga pembelajaran online berperan bukan menggantikan pembelajaran secara tatap muka tetapi mengkombinasikan antara pembelajaran online dengan pembelajaran secara tatap muka.

Hasil analisis memperlihatkan $79 \%$ mahasiswa setuju dengan perlu adanya informasi aktivitas pembelajaran yang akan dilakukan di dalam kelas online. Analisis yang ketiga terkait dengan sumber belajar dan bahan ajar, hasil analisis memperlihatkan $89 \%$ mahasiswa menyatakan perlu adanya sumber belajar atau bahan ajar yang disediakan dalam online.

Sumber belajar atau bahan ajar dapat mendukung kesiapan mahasiswa dalam proses pembelajaran. Sumber belajar dapat disajikan dalam berbagai bentuk, seperti: manual book, modul, gambar, video pembelajaran, yang disesuaikan dengan materi yang akan disampaikan. Menulis hasil perkuliahan tiap pertemuan dan file presentasi dosen atau materi ajar ke dalam pembelajarn online merupakan cara yang digunakan dan efektif untuk memberi mahasiswa akses jaringan online secara berkelanjutan (Bath \& Bourke, 2010), sehingga mahasiswa dapat mengulang kembali materi yang telah dipelajari secara mandiri. Kualitas pembelajaran merupakan hal yang sangat penting dalam pembelajaran online, serta isi juga harus memiliki keramahan terhadap peserta didik (Balaji et al., 2016).

Isi multimedia pembelajaran interaktif dapat meningkatkan motivasi, hal ini sangat sesuai untuk menjadi isi dalam pembelajaran online karena memuat komposisi visual, audio dan audiovisual. Pada aspek kemudahan akses, hasil analisis memperlihatkan $24 \%$ mahasiswa menyatakan online mudah untuk diakses, 53\% mahasiswa menyatakan internet cukup bisa diakses, dan 23\% mahasiswa menyatakan sulit diakses internetnya. Aksesibilitas merupakan tingkat kenyamanan seseorang untuk mencapai tujuan yang berhubungan dengan perilaku komunikasi. Sebagian besar mahasiswa mengakses online dengan menggunakan smarthpone maupun laptop, hal ini dikarenakan dalam 
proses internet diwilayah Kabupaten Purworejo terkendala letak geografis rumah tinggal mahasiswa yang dipegunungan sehingga sinyal sulit didapatkan. Berikut gambaran skor persentase akses internet di wilayah tempat tinggal mahasiswa:

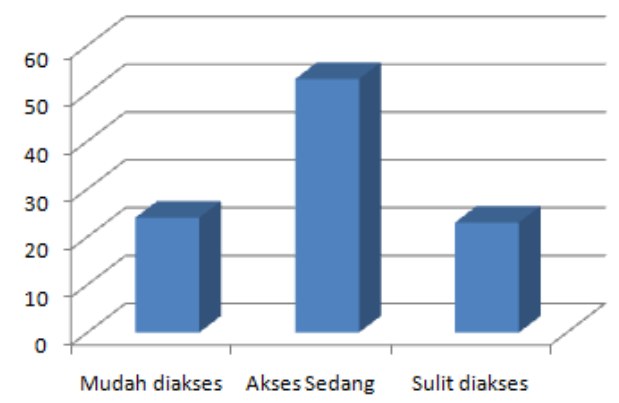

Gambar 2. Jaringan internet di wilayah mahasiswa bertempat tinggal

Aspek kemudahan dalam penggunaan, berdasarkan hasil analisis diperoleh $78 \%$ mahasiswa menyatakan online mudah untuk digunakan, sedangkan $22 \%$ mahasiswa menyatakan tidak mudah untuk digunakan. Hal ini dapat disebabkan oleh mahasiswa yang belum terbiasa dalam menggunakan online, serta masih minimnya dosen yang menggunakan internet sehingga mahasiswa tidak secara rutin menggunakan internet dalam proses pembelajaran.

Selain itu, persepsi seseorang terhadap pembelajaran online mempengaruhi kemauan dalam menggunakannya atau tidak, dan kemudahan seseorang dalam menggunakan teknologi akan memberikan pengaruh pada peserta didik. Berdasarkan segi kebermanfaatan penggunaan pembelajaran online dalam proses perkuliahan, hasil analisis diperoleh $88 \%$ mahasiswa memberikan respon bahwa online memberikan manfaat dalam proses pembelajaran. Sehingga dapat dinyatakan aspek yang dianalisis dalam cakupan kebermanfaatan antara lain: membantu pembelajaran, membantu belajar mandiri, meningkatkan motivasi, memudahkan materi. Hasil analisis tersaji pada gambar 3. 


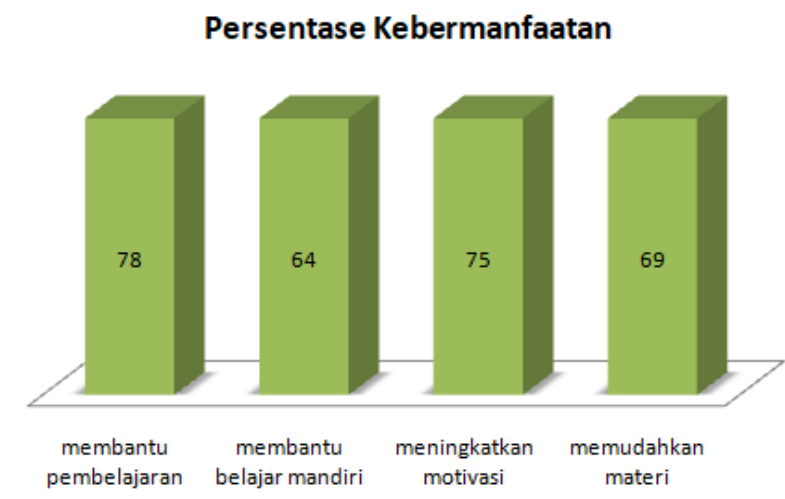

Gambar 3. Kebermanfaatan Pembelajaran Online

Mahasiswa menyatakan pembelajaran online dapat membantu dalam perkuliahan, dengan pendidikan online dan peluang untuk interaksi online pada mahasiswa dapat mengakses materi kelas online dan mengetahui gambaran aktivitas yang akan dilakukan dengan mempelajari instruksi maupun desain pembelajaran online, sehingga materi digunakan untuk belajar secara mandiri dan dosen akan lebih dapat melakukan eksplorasi pembelajaran online karena mahasiswa diharapkan memiliki kesiapan terhadap pembelajaran yang akan dilakukan.

Pembelajaran Online membantu mahasiswa untuk mempelajari materi secara mandiri selama pandemic Covid-19 atau pembelajaran jarak jauh, dengan mempelajari materi yang disediakan melalui pembelajaran online dapat meningkatkan motivasi mahasiswa dalam proses perkuliahan. Pembelajaran dengan Online berbeda dengan pembelajaran secara konvensional, dimana dalam pembelajaran dengan pembelajaran online dosen tidak berperan sebagai sumber informasi utama yang menyalurkan informasi kepada mahasiswa.

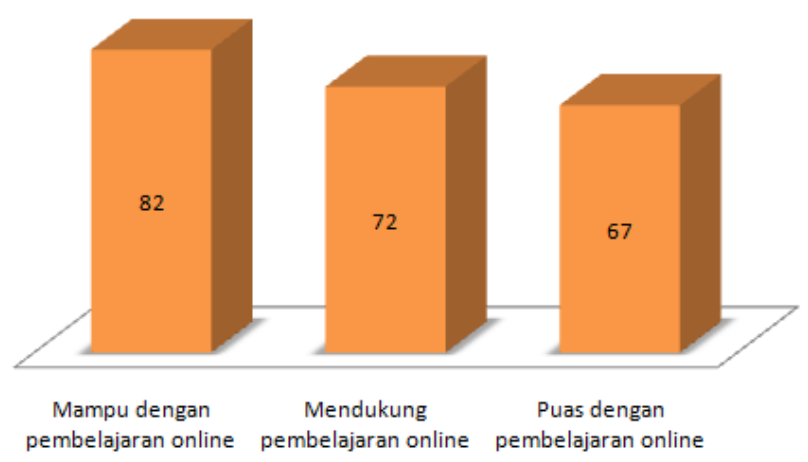

Gambar 4. Persepsi Penilaian Pembelajaran Online 
Hasil analisis kepuasan mahasiswa dalam menggunakan pembelajaran online, diperoleh hasil $67 \%$ mahasiswa menyatakan puas setelah menggunakan online, $72 \%$ mahasiswa mendukung pembelajaran online, dan $82 \%$ mahasiswa mampu melakukan pembelajaran online. Penerapan pembelajaran online dengan menggunakan media online; google classroom, zoom meeting, email, google meet, dan lain sebagainya.

Dari pembelajaran online dapat disimpulkan bahwa dengan adanya pembelajaran online ini mahasiswa dapat tetap mengikuti perkuliahan di masa pandemi Covid-19 atau dari rumah, serta meningkatkan daya pemahaman teknologi informasi. Hal ini disebabkan adanya rangsangan pikiran, perhatian, dan motivasi mahasiswa dengan model pembelajaran online. Ada beberapa persepsi mahasiswa yang menjadi catatan terhadap mata kuliah produktif yang disampaikan dengan pembelajaran online kurang memberikan tantangan kepada mahasiswa, sehingga tidak memberikan kesempatan kepada mahasiswa untuk praktik secara langsung, akibatnya ketrampilan tidak berkembang secara optimal, informasi pembelajaran yang diterima mahasiswa menjadi kurang memberikan kesan yang mendalam, dan hanya tersimpan sementara pada diri mahasiswa, sehingga hasil belajar praktik mata kuliah produktif mahasiswa menjadi menurun.

\section{KESIMPULAN}

Mahasiswa memiliki persepsi yang cukup baik terhadap pembelajaran online, hal ini dipengaruhi oleh demografi wilayah Kabupaten Purworejo dan pengetahuan mahasiswa dalam menggunakan pembelajaran online. Mahasiswa menunjukkan kesediannya melakukan pembelajaran online sebesar $88 \%$, selain itu mahasiswa mendukung dalam pembelajaran online terdapat aspek yang harus dilakukan dengan online, gambaran pembelajaran yang akan dilakukan di kelas online, serta materi yang dapat dipelajari sebelum pembelajaran secara tatap muka. Tingkat kepuasan mahasiswa dalam penggunaan online mencapai $67 \%$, mahasiswa mampu melakukan pembelajaran online $82 \%$, dan mahasiswa mendukung pembelajaran online $72 \%$. 
Perlunya dikembangkan pembelajaran dengan mengkombinasikan online dengan model pembelajaran langsung khususnya praktikum, sehingga pembelajaran online dapat lebih dimaksimalkan pada materi teori apalagi dimasa pandemi Covid-19.

\section{DAFTAR PUSTAKA}

Aziz, A. L., Al Musadieq, M., \& Susilo, H. (2013). Pengaruh Kemudahan Penggunaan Terhadap Kemanfaatan pada Sikap Pengguna E-Learning. Jurnal Administrasi Bisnis, 6(2). Retrieved from https://media.neliti.com/media/publications/78252ID-pengaruhkemudahan-penggunaan-terhadap-k.pdf Balaji.

R., Al-Mahri, F., \& Malathi, R. (2016). A Perspective Study on Content Management in E-Learning and M-Learning. eprint arXiv:1605.02093. Retrieved from http://arxiv. org/abs/1605.02093.

Bath, D., \& Bourke, J. (2010). Getting Started with Blended Learning. Queensland: Griffith University. Retrieved from http://tdu.nmmu.ac.za/Blended-Learning.

Donnelly, R., \& McSweeney, F. (2009). Applied E-Learning and E-Teaching in Higher Education. Applied E-Learning and E-Teaching in Higher Education. https://doi. org/10.4018/978-1-59904-814-7

Graham, C. R. (2006). Blended Learning Systems:Definition, Current Trends, and Future 109 E-Learning dalam Persepsi.

Muzid, S., \& Munir, M. (2005). Persepsi Mahasiswa Dalam Penerapan e-Learning sebagai Aplikasi Peningkatan Kualitas Pendidikan (Studi Kasus Pada Universitas Islam Indonesia). Seminar Nasional Aplikasi Teknologi Informasi 2005 (SNATI 2005) (Vol. 2005, p. 8). Yogyakarta.

Riawan Yudi Purwoko, Rusgianto Heri Santosa, Sugiman. 2020. Developing Mathematics Learning Instruction Based on Pedagogical Content Knowledge of Professional Teachers in Indonesia. Journal of Talent Development and Excellence. 12 (1), 4375 - 4387

Singh, G., O 'donoghue, J., \& Worton, H. (2005). A Study Into The Effects Of eLearning On Higher Education. Journal of University Teaching \& Learning Practice, 2(1). Retrieved from http://ro.uow.edu.au/jutlp

Wicaksono, S. R. (2015). Computer Supported Collaborative Learning Berbasis Blog. Malang: Seribu Bintang. 